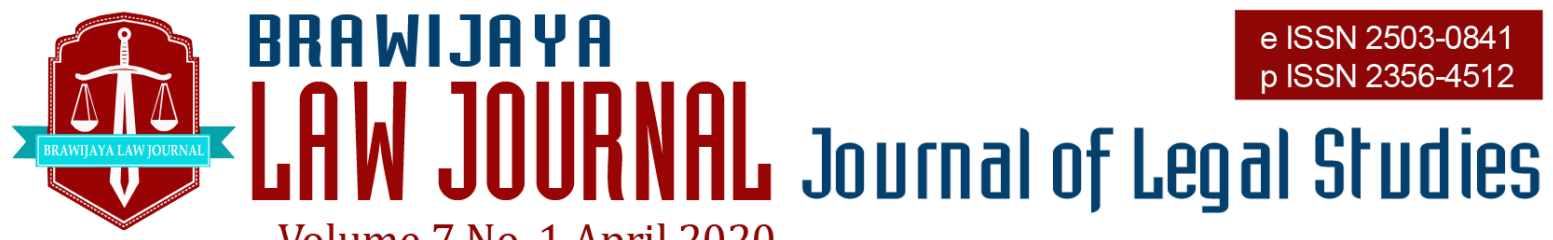

Volume 7 No. 1 April 2020

Nationally Accredited No. 30/E/KPT/2018 Dated 24th October 2018

This work is licensed under a Creative Commons Attribution-NonCommercial 4.0 International License

\title{
Institutional Policy in Land Procurement Under The Omnibus Law Regime
}

\author{
Imam Koeswahyono ${ }^{\text {, Hikmatul Ula }}{ }^{\mathrm{b}}$ \\ ${ }^{a}$ Faculty of Law, Universitas Brawijaya, \\ Email: imam.koes@ub.ac.id \\ ${ }^{b}$ Faculty of Law, Universitas Brawijaya \\ Email: hikmah_ula@ub.ac.id
}

Submitted : 2020-03-06 | Accepted : 2020-04-23

\begin{abstract}
The legal culture procedure with socio-legal analysis will be able to answer the fundamental questions in the problems of practices of land procurement for public interests, in particular the issue of compensation. The crucial issue of compensation within the implementation of the policy of land procurement regards the non-equivalence of land value, both utility value and economic value of structures and landscapes, to the monetary compensation. The use of the legal culture approach is to provide answers and implement them to resolve issues of land procurement for public interests in the omnibus law regime to maintain justice to landowners and preserve the environment. The correlation of the cultural approach and activities of land procurement is that culture refers to the target of the national conscience, and the cultural approach based on the growth mindset will result in wisdom and nobility of the decisions of public officials to prioritize the people rather than interests of investment. The government must choose to renegotiate the policy of enacting the Law of Employment Creation, which is judged by the greater public to conflict with the spirit and mandate of the Preamble and contents of the 1945 Constitution. It needs renegotiation between the state and people by discussing in-depth the legal substance of the law is not performed, and then the law in question must have its enactment firmly rejected.
\end{abstract}

Keywords: land procurement; legal culture; omnibus law

\section{INTRODUCTION}

One of the products of legislation that need to enact during the Second United Indonesia Cabinet is Law No. 2 of the Year 2012 on Land Procurement for Development, which has generated support and opposition among people in society. Certainly, of the several supporting and opposing opinions generated by various elements of society possess differing bases of reason, argumentation, and viewpoints. ${ }^{1}$
1 Confer the article by the author from a totally renewed article published in the "Majalah Arena Hukum" of the Faculty of Law, Brawijaya University, No. 8 Year 4 July 2011 p. $115-124$ and Jurnal Hukum dan Pembangunan, Faculty of
Law University of Indonesia. Acknowledment I must thank the reviewer who shared their constructive and contributed their awesome knowledge. Also thanks to Airin, Dyah Pawestri, Yolanda and Bastiko Pradana who translated 
One of the opposing opinions that have expressed at the time the law was discussed at the National People's Representative Council was by Idham Arsyad, who in brief stated that the discussion of the law as a bill should have delayed until structuring of agrarian affairs performed by inciting the execution of agrarian reforms. ${ }^{2}$ Before this, the daily newspaper "Kompas" also reported that the land procurement law is a threat to land rights because it is prone to be misused for business interests that instead hinder public access to development, and thus it is considered to not support public interests. ${ }^{3}$

The essence of this article is not to discuss why there is a debate that occurs regarding differences of views among stakeholders but to discuss the philosophy, theories, and consequences of the institutional policy in land procurement for public interests, assuredly from a legal standpoint or perspective. Why is there a specific urgency for the discussion regarding the analysis of the subject? The reason of the author is because in general, articles that discuss land procurement for public interests are seen as one of the causes of conflicts over land resources, including the actors who are involved, the legal actions initiated by the actors, the resulting unfavorable effects of those legal actions on other parties, and the efforts that are taken by parties whose land resource assets are affected by activities of development for public interests to struggle to regain their rights.

The materials for this article approach the problem of land procurement for public interests from a different perspective by asking, "Why is it necessary to have an institutional policy in land procurement?" This formulated question becomes the trigger for discussion through the formulation of the problem.

perfectly, I could not have written it better without them.

2 Idham Arsyad, 'Sesat Pikir RUU Pengadaan

Tanah' [Misguided Views of the Land

Procurement Bill], Kompas, (Friday, March 18, 2011), 6

3 Editorial, 'Ancaman Hak Atas Tanah' [Threat to Land Rights], Kompas, (Friday, March 11, 2011) 4.

\section{LEGAL MATERIALS AND METHOD}

This research paper uses the judicialnormative research method to answer the legal problems. Relevant regulation or law regarding the land procurement and omnibus law will be analyzed.

Moreover, the paper also uses the conceptual approach to solve the problem from philosophy, theories, and consequence of the institutional policy in the land procurement for society interest. It also uses legal culture approach to found the best strategic that must be carried out by the government to resolve the issues of the application of an institutional policy in land procurement for public interest in the omnibus law regime.

\section{RESULT AND DISCUSSIONS}

\section{Land Procurement for Public Interests in the Perspectives of Legal Concept and Philosophy \\ a. Legal Concept}

Before approaching analysis by legal philosophy, it is necessary to equalize perceptions on the actual concept of land procurement for public interests. In general, it could say that land procurement is a method or effort to obtain or possess the land for specific interests or aims. Meanwhile, public interests are often contrasted with individual or personal interests or pitted against non-public interests.

The linguistic meaning of "public interests" is the requirements and obligations of many people and society. ${ }^{4}$ As such, it could understand that public interests are the effort of the fulfillment of needs with the intent to serve the society or a group of people. $^{5}$
Tim Prima Pena, n.d., Kamus Lengkap Bahasa Indonesia [Complete Dictionary of the Indonesian Language], (First Printing, Gita Media Press, n.p.), 507 and 663.

5 Based on data from the Coordinating Ministry for the Economy of the Republic of Indonesia and the Ministry of Agrarian Affairs and Spatial Planning/National Land Agency, land procurement activities up to December 2019 for strategic national projects have resulted in more 


\section{b. Legal Philosophy}

The question on the legal philosophy perspective on how land for people has positioned as the subject of a right leads to the problem of utility or usefulness. The concept of utilitarianism in the legal field of discipline belongs to classical positivism, which in general has often put in opposition to classical naturalism, for which Hilaire McCoubrey and Nigel D. White say its supporters "treat law as a prescription deriving its ultimate authority from a 'purpose' morality, by reference to which its 'law' quality may be judged." ${ }^{6}$ Meanwhile, positivist theories of law have defined as "these which concentrate upon a description of law as it is in a given time and place, by reference to formal, rather than to moralethical, criteria of identification". ${ }^{7}$ In the legal field of discipline, the concept of utility was put forward and developed by Jeremy Bentham (1784-1832), which then was critiqued by John Austin, who called it the principle of utility; the essence of utilitarianism according to Jeremy Bentham is "the happiness of the individuals, of whom a community is composed, that is their pleasure and their security, is the end and sole end which the legislator ought to have in view."

A similar opinion regarding what is meant by utilitarianism was presented by Davies and Holdcroft:

than 38,000 hectares. Construction of 60 toll roads with an area of 16,582 hectares, two Special Economic Zone projects with an area of 8,183 hectares, twelve (technical) irrigation projects with an area of 768.02 hectares, and 16 railroad networks with an area of 728.6 hectares will become more facilitated to ease the progress of the projects with the Law of Employment Creation, and yet the projects threaten efforts of conserving the natural resources of forests, beaches or coastal areas, conservation areas, and protected areas. Refer to the Presentation of the Report by the Coordinating Ministry for the Economy and the Ministry of Agrarian Affairs and Spatial Planning, published at www.atrbpn.go.id, accessed on February 20, 2020. It is possible that in a process that occurs with a specified target length of time, because the emphasis of the legal politics of the Law of Employment Creation is to ease or at its extreme to erase permits that are seen by investors to impede investment, the government as a public
"Utilitarianism is a goal-based theory that evaluates actions in terms of their propensity to maximize goodness, however, this is defined. Hence, it takes the view that our conception of what is right depends on our conception of what is good since the right action is defined as one which produces more good than any alternative. So that only if a person has a conception of what is good can he or she have one what is right. ${ }^{9}$,

As an affirmation for understanding what is utilitarianism and how it has realized according to Davies and Holdcroft, Murphy and Nagel stated that:

"Utilitarianism takes the happiness or welfare of individuals as the basic currency of moral evaluation and assesses outcomes by subtracting the overall costs from the overall benefits, measured in these terms. Utilitarianism holds that one should try to maximize the total happiness of the members of a society in designing its policies and institutions. ... It doesn't mean that each official act should aim at increasing the general welfare, since some of the most useful institutions for promoting the general welfare such as property rights and the legal system depend on adhering

organization and private organizations commit corruption of permits due to the malfunction of good corporate governance and weak state institution, thus resulting in "State Capture". Refer to Hariadi Kartodihardjo and Sudarsono Soedomo, 'Area Regime and the Politics of Its Usage Reallocation: A Historical, Management, Institutional, and Bureaucratic Overview' [Rezim Kawasan dan Politik Realokasi Penggunaannya: Tinjauan Historis, Tatakelola, Institusi dan Birokrasi], (paper for the National Symposium of Agrarian Reform Implies Forestry Reform, organized by IPB, ForciDeV dan FOReTIKA, Jakarta, 2020) 16-18.

6 Hilaire McCoubrey, Nigel D White, Textbook on Jurisprudence, (Blackstone Press Limited, Second Edition, Glasgow, 1996), 11.

7 Ibid, 11.

8 Ibid, 29.

9 Ian McLeod, Legal Teory (Palgrave Macmillan, $4^{\text {th }}$ Ed, New York, 2007), 170. 
to certain rules, without considering the general welfare in each case. But the ultimate standard, whether acts, laws, conventions or policies are being evaluated, is the overall effect on people's happiness or welfare." 10

Referring to the views of James M. Donovan, it has stated that "Such laws seek to maximize the pleasure and minimize the pain of the society, evoking principles that would become familiar under the label of utilitarianism. Because what causes both pain and pleasure is often rooted in human nature, legitimate laws will reflect the contours of these natural predispositions." 11 As such, it is clear that about utility, there needs to be a spesific criterion, measure, or parameter, not just for individuals but also for society, which Murphy and Nagel call a "metric." This raises a debate, particularly on the question of whether the benefit of something is subjective or individualistic and how to measure utility to be able to appropriately compare, expand, and see its effects or consequences on different people. As stated by Raymond Wacks, "The essence of utilitarianism is its consequentialism. It is important, therefore, to distinguish consequentialists from deontological systems of ethics. ${ }^{12}$ Because the essence of utilitarianism is consequentialism, this means that utility has understood as a consequence or result that may very well be separated from something that becomes its cause, for example regarding wrong or right.

Therefore, the view on utility, whether with the normative or moral standard, regards something that is coming because it aims for maximizing happiness, prosperity, or other good objectives. This has accomplished through the addition of measures or criteria for advantages and disadvantages of individual lives that are different from one

10 Liam Murphy and Thomas Nagel, The Myth of Ownership, (Oxford University Press, First Printing, New York, 2002), 51 confer Francis Wahono, Ekonomi Politik Daulat Rakyat: Pancasila Sebagai Acuan Paradigma, (Buku KOMPAS, $1^{\text {st }}$ Ed, Jakarta, 2020), 3-9. another to obtain the magnitude of a specific value for the evaluation of utility from a particular insight.

Thus, in order to achieve the stated goals of utility:

"The happiness of people (eudaimonism) as theorized by Socrates, which are good deeds that lead to joy, is not limited to happiness that is pursued by individuals according to the concepts of David Hume or even Jeremy Bentham, which have an egoistic characteristic and is not in line with values of peoples outside of Europe. Thus from the standpoint of justice, the interests of other people (the masses) must be prioritized in social life. Therefore, the measures of good deeds are actions that bring about the greatest good for the greatest number.",13

The concept of utilitarianism, as presented by both Jeremy Bentham and David Hume, was perfected by their follower, John Stuart Mill, about the sharp criticism from John Rawls. Rawls stated his view regarding the concept of utilitarianism through a detailed example:

"And so by reflections, naturally reaches the principle of utility: a society has properly arranged when the institution maximizes the net balance of satisfaction. Social justice is the principle of rational prudence applied to an aggregative conception of the welfare of the group. The striking feature of the utilitarian view of justice is that it does not matter, except indirectly, how this sum of satisfactions is distributed among individuals any more than it matters, except indirectly, how one man distributes his satisfactions over time.

11 James M. Donovan, Legal Anthropology, An Introduction (Alta Mira Press, Lanham, UK, 2008), 34.

12 Raymond Wacks, Understanding Jurisprudence: An Introduction to Legal Theory, (Online Resource Centre, Oxford University Press, $3^{\text {rd }} \mathrm{Ed}$, New York, 2012), 214.

13 Ibid, 21-22. 
The correct distribution, in either case, is that which yields the maximum fulfillment. Society must allocate its means of satisfaction whatever these are, right and duties, opportunities and privileges, and various form of wealth, to achieve this maximum if it can." 14

Rawls adds that "On this conception of society separate individuals are thought of as so many different lines along which rights and duties are to be assigned and scarce means of satisfaction allocated by rules as so to give the greatest fulfillment of wants. Utilitarianism does not take seriously the distinction between persons." ${ }^{15}$ As a follower of legal realism, according to Rawls, individual freedom cannot be ignored, particularly in the modern era, because with this freedom, people can develop their imagination and creativity, which will bring about benefits for individuals as well as society. Conversely, for societies that have not been well established or ordered, for the principle of justice to be able to protect all people, the people must return to their original position. For them to return to their original position, then, according to Rawls, two basic principles must be fulfilled:

"First, each person is to have an equal right to the most extensive basic liberty compatible with a similar liberty for others.

Second, social-economic inequalities are to be arranged so that they are both a, reasonably expected to be everyone's advantages, and $b$, attached to positions and offices open to all." 16

The philosophical bases that must become the foundation for the Law of Land Procurement for Public Interests, in addition to Law No. 5 of the Year 1960 on basic

14 John Rawls, 1999, A Theory of Justice, (Belknap Press of Harvard University Press, Revised Edition, USA, 1999) 24, 26.

15 Ibid, 27.

16 Ria Mardiana Yusuf and Muh Guntur, Menuju Kepemimpinan Yang Berkeadilan Sosial [Towards Leadership with Social Justice], in Jurnal Keadilan Sosial, First Edition: Antara Keadilan Sosial dan Keadilan Hukum [Between
Fundamental of Agrarian, include the Pancasila and specifically the second, fourth, and fifth principles as has been stipulated in the preamble of the Law, Letters a and b. It should be that the inclusion of the philosophical bases must affirm that the intended development activities are designated for some interests, carried out in a particular manner, and outlined in specific steps. The five principles of the Pancasila, as stated by Notonagoro (1984), constitute the substance, guidance, and essence of each norm, which in this case is of the legal regulations to formulate.

The same article by Notonagoro also states that:

"All legal regulations present in the country of Indonesia since its founding constitute a legal system, the legal system of Indonesia. In each legal system, there is a hierarchical division of structures. Each legal regulation that is enacted should be a formulation of the values contained in the five principles of the Pancasila, which should be the qualification of the formulation of the first principle in an arrangement of unity with the other principles. ",17

In every legal system, the primary essence is the synchronization and harmonization of legal regulations in a sequence of levels, as formulated by Hans Kelsen and Hans Nawiasky, like an order that is systematic, logical, and rational in the framework of a particular legal system. When carefully examined, in the preamble there is a stipulation of legal politics as the following:

a. To realize a fair, prosperous, and secure society based on the Pancasila and the 1945 Constitution of the

Social Justice and Legal Justice], ILRC and OCI, Jakarta, 2010), 59-60.

17 Notonagoro, Beberapa Hal Mengenai Falsafah Pancasila [Several Matters Regarding the Pancasila Philosophy], (Speech for the First Anniversary of Pancasila University, Djakarta, Eighth Printing, Pantjuran Tudjuh, Djakarta, 1979), 20 and 33. 
Republic of Indonesia, the government needs to carry out development;

b. To ensure the organization of development for public interests, there needs to be land for which its procurement is carried out in ways that prioritize principles of humanity, democracy, and fairness;

c. The legal regulations in the field of land procurement for development for public interests have not been able to ensure the acquisition of land to carry out such development;

$d$. Based on the considerations as stated in Letter a, Letter b, and Letter c, a Law needs to be created on the Procurement of Land for Development for Public Interests.

It may have stated philosophically that Law No. 2 of the Year 2012 has seemingly intended to carry out the mandate contained in the principles of Pancasila concerning the principles of humanity, democracy, and justice, though it is undeniable that the national philosophy has acquired influence from globalization with the neo-capital and liberal ideologies.

Considering the objects of institutions of land procurement, which would be called land resources, particularly for Indonesia as an agrarian country, land resources have a strategic position. As stated by Mochammad Tauhid, "agrarian affairs (land affairs) are affairs of human living and livelihood, because the land is the origin and source of food. Affairs of land concern living, as the blood that supports the living bodies of people. Whoever controls the land, controls food as well." 18

As such, it can understand why land resources in the context of the country of Indonesia have a very high value for their rights subjects, being the only source of

18 Mochammad Tauhid, Masalah Agraria Sebagai Masalah Penghidupan dan Kemakmuran Rakyat Indonesia [Agrarian Affairs as an Issue of Livelihood and Prosperity of Indonesian People], Book One, (Bina Desa Foundation, Fourth Printing, Jakarta, 2011), 3-4.

19 Friedman, Lawrence M, The Legal System: A Social Science Perspective, (New York: Russel sage Foundation, 1977), p. i-ix, 1-5; it is livelihood as well as respect. This is why given two parties, for which one party requires land and the other party possesses land and the two parties are unable to agree, this will become the beginning of a dispute on land resources (tenurial conflict).

If land resources have seen as a source of livelihood as well as respect, according to the perception of most Indonesian people, whose primary livelihoods are in the field of agriculture, the question becomes how the law as a legal instrument can regulate reasonably and beneficially the relationships of Indonesian people with the land resources. Therefore, it is only fair that the government on behalf of the state in creating policies as mandated by Article 33 Paragraph (3) of the 1945 Constitution of the Republic of Indonesia with control of rights by the state, must serve the greatest prosperity of all people. Conversely, government policies that implement control of rights by the state have not designed to increase the prosperity of all people in violation of the constitution.

\section{Land Procurement for Public Interests According to Legal Culture, Legal Politics and Legal Theory}

\section{a. Legal Culture}

Before discussing and offering criticism on what is meant by legal culture, regarding the urgency of conducting a study involving it as well as its relevance to a study on the issue of land procurement, its understanding needs to explain. In contrast to what had been explained by Lawrence M. Friedmann (1977) regarding legal culture as one of the parameters to measure the legal consciousness of a particular society on a court verdict given for a specific conflict in a one sub-field or branch of legal science such as criminal, civil, or administration law as well as other sub-disciplines of legal science $^{19}$, "legal culture" can be understood

\footnotetext{
interesting to compare the writings of Friedman with that of Sulistyawati Irianto as in Sulistyawati Irianto, Pendidikan Hukum Untuk Indonesia Masa Depan: Sebuah Catatan Kritis [Legal Education for a Future Indonesia: A Critical Remark], (Scientific Oration, Open Senate Meeting for the $74^{\text {th }}$ Anniversary of the Faculty of Law of Gadjah Mada University, Yogyakarta, 2020) p. 6, which affirms the inevitability that if
} 
as the viewpoint of a society at a certain period on a specified matter, whether regional, national or global, according to a specific perspective or ideals such as the national philosophy of Pancasila or another philosophy. As such, the relationship between cultural studies and the discipline of legal science is a branch of humanities that examines how the feelings or desires of people or society regarding the fundamental values of legal certainty, legal utility, and legal justice are manifested and accepted as something that is self-evident and becomes the benchmark in the reality of legal relationships.

In general, the view of the author is that judicial science is a part of cultural education that is understood as an interdisciplinary academic practice or study because many of its analyses borrow theories and or concepts from various fields of disciplines. ${ }^{20}$ Budiono Kusumohamidjojo stated that the phenomenon of culture is not a phenomenon of nature; it is a very complex phenomenon and an empirical reality, and thus it requires

concordance is desired between theoretical law and law in practice, then the same is true between the discipline of law with the social science discipline of humanities through an interdisciplinary approach.

20 Agnes Setyowati, Cultural Studies: Sebuah Pengantar, Teori dan Konsep [Cultural Studies: An Introduction, Theories, and Concepts], (Mitra Wacana Media, Bogor, 2019), 1.

21 Ibid, 3.

22 The matter of disruption refers to the views of Rhenald Kasali, who stated that change drives people to adjust and harmonize mindsets composed of assumptions that are followed by them and are no longer appropriate to new needs. In simple terms, mindset is a set of assumptions; Carol Dweck of Stanford University, USA, divided mindset into the two kinds of fixed mindset and growth mindset. Confer Rhenald Kasali, Strawberry Generation, Mengubah Generasi Rapuh Menjadi Tangguh [Strawberry Generation: Changing a Fragile Generation to a Strong Generation], (Rumah Perubahan dan Mizan, Jakarta, 2017), 3; management expert Steven Covey affirmed that one should "begin with the end in mind", which means that if a person desires success, then the person must possess the integrity to improve and increase confidence, for which Donald Trump considers that success is derived from behaviors and confidence of ability; according to a multidisciplinary understanding. ${ }^{21}$ Culture will affect the behaviors of people who interact with one another both vertically and horizontally, as influences that are positive such as the creation of a system of consciousness of or compliance to all stipulations of the state, and viewpoints regarding matters that have based on the values of honesty and reasonableness. Applying the three different elements of culture by Koentjaraningrat, composed of Cipta (thought), karsa (intention), and rasa (feeling), cultural studies are included as the elements of rasa and karsa because it explains logically the will of each individual to control egoistic interests, in upholding values such as piety, honesty, good intent, tolerance.

Within more or less the past two decades, intense changes have occurred in all parts of life in society in all parts of the world with science and technology coming into dominance, resulting in major shifts of occupations, which is a phenomenon known by the term of "disruption". ${ }^{22}$ Disruption has

Koentjaraningrat, Kebudayaan, Mentalitet dan Pembangunan [Culture, Mentality, and Development], (Gramedia, $3^{\text {rd }}$ Printing, Jakarta, 2016), 50-53, underestimation of quality is understood as a lack of self-respect as well as a lack of (fair and healthy) competition to achieve optimal results from work due to low motivation, and even if there is motivation, the emphasized targets are directed toward pure numerical achievements, without prioritizing the process aspect. The mentality of taking shortcuts is the attitude of emphasizing results without harmonization with changes or developing situations, an open attitude, or the will to work hard, but expecting optimal results. An attitude of not being confident in the abilities of the self and a nature of impure discipline is called a fixed mindset; conversely, an attitude of being open to input, suggestions, and criticism that makes a person open to insights, willing to adapt to change, and enjoy improving and increasing their selfqualities is called a growth mindset. Confer Billy Boen, Young on Top, 30 Rahasia Sukses di Usia Muda [Young on Top: 30 Secrets of Success at a Young Age], (TransMedia, Jakarta, 2009), 50-56 who put forth the term of "open-minded". "Openminded" means being mindful of uncertainties in the realm of life, being able to open up the realm of thoughts and creating important decisions no matter what they are, and able to realize in some way ideas or concepts creatively and positively. 
incited a large-scale revolution wherein the intelligence of human beings is being replaced by artificial intelligence, including in legal professions such as legal consultants, attorneys, and notaries, which are being replaced by various and sophisticated digital applications in the 4.0 or even 5.0 eras. Regarding activities of land procurement for public interests as regulated in Law No. 2 of the Year 2012 as well as the earlier stipulations of Presidential Decree No. 65 of the Year 2006 above all requires that mutual consensus be present to realize the legal culture of Indonesian society for the validity of legal actions. The validity of legal actions in agreements as regulated in Article 1320 of the Civil Law Code prioritizes a subjective requirement, which is the capability to act and make agreements. Article 37 Paragraph (1) of Law No. 2 of the Year 2012 even stipulates that land institutions must conduct deliberations with the parties that hold rights within at most 30 working days after an appraisal or evaluation has been carried out by the team of evaluators to determine the form and/or amount of compensation. As such, from a cultural perspective, the mainstreaming of cultural elements that are rooted in the Indonesian tradition prioritizes mutual agreement in decision-making for the greatest priorities of the nation. Through a cultural approach that is based on the mentality of growth mindset, this will generate the wise attitude of the government to not view the issue of land procurement as merely the interests of the government. This means that the people or landowners are not permitted to reject the decision of the government to surrender the land to investors. Yet, the added value from activities of land procurement for public interests for the people, particularly the former landowners, is not significantly proven. Referring to the results of a study by the Corruption Eradication Commission (KPK) from May 2004 to May 2017, 650 cases occurred and $80 \%$ of those who commit corruption involves the public sector and private sector

In conclusion to what has been presented, the importance of a mindset is as a way for public authority officials to start to change their ways of with the primary modes of extortion, bribery, and kickbacks, which affects the policies of state organizers. ${ }^{23}$ The enactment of the Law of Employment Creation, as stated in a declaration of views by the Madani Foundation in a press conference on April 15, 2020, will weaken legal regulations on the protection of forests, nature, and the environment; this will cause deforestation, failure to save 3.4 million hectares of forest land in areas of palm oil plantations, the threat of decreasing natural forest coverage in 45 watersheds in West Papua Barat in 2058 by $0 \%-20 \%$, land conversion of agricultural lands with technical irrigation, and still many other damaging impacts.

\section{b. Legal Politics}

The term of "legal politics" in the legal field of discipline still becomes a discourse of debate among experts of both legal science and social science, regarding whether it qualifies as one of the parts of the field of discipline of legal studies or a part of the field of discipline of social science and specifically political science. This article does not attempt to enter the debate; instead, it focuses on the examination of the true essence of constitutional politics in connection with Law No. 2 of the Year 2012 on Land Procurement for Development for Public Interests by comparing the legal regulations that precede it.

Mahfud MD provides a description that further clarifies what is meant by legal politics as written in his dissertation, which has caused controversy of opinions by referring to Belinfante regarding the place of legal politics within legal science as arranged in a "tree".

"The tree of legal science consists of the roots of legal science, as the national philosophy and ideology of Indonesia, which is Pancasila. The stem of the tree of legal science contains the fibers of the tree (or subsystems of society) such as history, politics, economy, culture, and

thinking as an effort to pave the way toward success their tasks handling land procurement.

23 Hariadi Kartodihardjo and Sudarsono Soedomo, above n 5, 17-18. 
administration. From here, this leads to studies of legal history, legal politics, legal sociology, and legal culture. A branch of legal science is positive law, which is differentiated into several main fields such as civil law, criminal law, constitutional law, and state administration law, which then give rise to the branches of legal science." $" 24$

The conclusion from the above-written explanation is that legal politics is a part of the studies of legal science and one of its branches that deals with norms of legal regulations as the objects of study, which through acts of the government along with representative institutions of citizens are revised, changed, replaced with new ones, or maintained to realize the legal objectives of justice and welfare for the whole nation. Legal politics has very significant importance to explain the facets that belie legal norms, as a guide to what direction ought to be taken through the formation, amendment, and improvement of laws in the future (das sollen).

It is in this framework that if legal politics is a branch or limb of the "tree" of legal science, then the "twigs" of legal science include the regulation of specific aspectual fields, one of which is the aspect of land procurement for development of public interests. The essence of land procurement for development of public interests is the will of the government on behalf of the state based on the stipulations of legal regulations to obtain land for the needs of activities that qualify as the development of public interests, including by taking land that is possessed by legal subjects, whether individuals or legal entities. However, in creating policies for the takeover of land, same condition are stipulated by Article 28G Paragraph (1) of the 1945 Constitution: "Each person is entitled to the protection of their selves, family, respect, dignity, and property under their domain, as well as entitled to safety and protection from the threat of fear to do or not do actions that are their rights." This is echoed by Article $28 \mathrm{H}$ Paragraph (4): "each person is entitled to possess personal ownership rights and these personal ownership rights may not be taken over at will by any other person."

Therefore, referring to the understanding of legal politics as explained by Mahfud MD, the essence of legal politics of land procurement for development of public interests is the realization of the will of the government to compose and change legal regulations for the planning, formation of institutions, realization, supervision, and evaluation of policies in this field based on social justice, the greatest utility for all people, and legal certainty.

The understanding of legal regulations for land procurement for the development of public interests is more appropriate when considering the history of the institution in the past, for which Minister of Domestic Affairs Regulation No. 15 of the Year 1975 was the institution for the acquisition of land rights. The institution for the acquisition of land rights was utilized by the New Order government to obtain or acquire land that has to allocated for activities of development for both the government and private groups.

This objective was indeed in agreement with the ideology developed at that time, which is "development" based on the "trilogy of development" and in particular a dynamic growth of the economy, although by law the minister regulation was in conflict with Law No. 5 of the Year 1960 on the Basic Regulations of Agrarian Affairs, which only recognized two legal institutions that form the basis government policies for land procurement for development of public interests. Here, the legal institutions are the voluntary ceding of rights to land by its owner as stated in Article 27 Letter a Number 2 and the revocation of rights to land and the objects present on it as established by Article 18 of Law No. 5 of the Year 1960, which states "for public interests, including interests of the nation and the state, as well as the shared interests of the people, rights on

24 Mohammad Mahfud MD, Membangun Politik Hukum, Menegakkan Konstitusi [Constructing

Legal Politics, Upholding the Constitution], (Rajawali Pers, $2^{\text {nd }}$ Printing, Jakarta, 2011), 2-3. 
land may be revoked, by providing proper compensation and according to methods regulated by laws." Article 18 was then regulated further with Law No. 20 of the Year 1961.

Conflicts of rights due to the execution of this legal institution have continued to be prevalent even though the Minister of Domestic Affairs Regulation was replaced by Presidential Decree No. 55 of the Year 1993 on the Procurement of Land for Conducting Development for Public Interests, which qualifies as the second pattern of land conflict as detailed by Maria SW Sumardjono. ${ }^{25}$ In another article, Maria Sumardjono takes the view that it is time that policies for the taking over of land must rely on the principle of democracy and uphold human rights, with consideration of the following:

\section{Land takeover constitutes legal actions} that have the consequence of the loss of rights of a person to both physical and non-physical objects, and the temporary or permanent loss of wealth;

2. The provided compensation must take into account 1) loss of rights over land, buildings, and plants; 2) loss of income and other sources of livelihood; 3) aid to move to another location by providing alternative new locations that have complemented with proper facilities, and 4) aid for the recovery of income to be equivalent to the state before the takeover;

3. Those who have evicted due to land takeover must be considered in the expanded provision of compensation;

4. To obtain accurate data on the people who are affected by evictions and the size of compensation, it is necessary to perform a basic and socio-economic survey;

5. It is necessary to implement an authority that is responsible for the execution of takeover and resettlement;

6. Methods to achieve mutual agreement must develop;

7. There needs to be a facility for handling complaints and resolving conflicts that may occur in the process of the land takeover. ${ }^{26}$

Referring to the guidelines outlined by Maria Sumardjono above, about how the legal politics of legal regulations on land procurement for development of public interests have realized from 2005 to 2012 , these descriptions have obtained:

Table 1. Comparison of Legal Politics of Legal Regulations on Land Procurement for Development of Public Interests

\begin{tabular}{|c|c|c|c|c|c|}
\hline No. & $\begin{array}{l}\text { Presidential } \\
\text { Decree No. } 55 \text { of } \\
\text { Year } 1993 \\
\end{array}$ & $\begin{array}{l}\text { Presidential } \\
\text { Regulation No. } 36 \\
\text { of Year } 2005 \\
\end{array}$ & $\begin{array}{l}\text { Presidential } \\
\text { 6Regulation No. } 65 \\
\text { of Year } 2006 \\
\end{array}$ & $\begin{array}{l}\text { Law No. } 2 \text { of Year } \\
2012\end{array}$ & Legal Analysis \\
\hline 1. & $\begin{array}{l}\text { To facilitate the } \\
\text { acquisition of } \\
\text { rights to land that } \\
\text { is required for } \\
\text { activities of } \\
\text { development } \\
\text { quickly and } \\
\text { easily, it is } \\
\text { necessary to } \\
\text { implement } \\
\text { regulations on }\end{array}$ & $\begin{array}{l}\text { With the } \\
\text { increased } \\
\text { development of } \\
\text { public interests } \\
\text { that require land, } \\
\text { its procurement } \\
\text { needs to } \\
\text { conducted } \\
\text { quickly and } \\
\text { transparently } \\
\text { while still }\end{array}$ & $\begin{array}{l}\text { To observe further } \\
\text { the principle of } \\
\text { respect toward } \\
\text { valid rights to land } \\
\text { and legal certainty } \\
\text { in land } \\
\text { procurement for the } \\
\text { execution of } \\
\text { development of } \\
\text { public interests, it } \\
\text { has considered }\end{array}$ & $\begin{array}{l}\text { - To realize a } \\
\text { society that is fair, } \\
\text { prosperous, and } \\
\text { secure based on the } \\
\text { Pancasila and the } \\
1945 \text { Constitution, } \\
\text { the government } \\
\text { needs to carry out } \\
\text { development; } \\
\text { - To ensure the } \\
\text { execution of }\end{array}$ & $\begin{array}{l}\text { - The presidential decree } \\
\text { has based on the } \\
\text { principle of state } \\
\text { philosophy and } \\
\text { synchronization of legal } \\
\text { regulations, and } \\
\text { therefore the presidential } \\
\text { decree conflicts with the } \\
\text { Pancasila philosophy } \\
\text { and the Law on Agrarian } \\
\text { Affairs; }\end{array}$ \\
\hline
\end{tabular}

25 Maria Sriwulani Sumardjono, Himpunan Kasus Beberapa Masalah Tanah [Compilation of Several Land Issue Cases], (Department of Agrarian Law, Faculty of Law, Gadjah Mada University, First Printing, Yogyakarta, 1982) p. iii; in this first article, Sumardjono found that there are three essential things that trigger conflicts of land procurement: 1) no progression of the process for mutual agreement, 2) small or low amount of compensation that is paid by the government to former land rights subjects, and 3) policies in the form of repressive actions that pressure land rights holders to relinquish immediately their legal relationships to their land.

26 Maria SW Sumardjono, Kebijakan Pertanahan Antara Regulasi dan Implementasi [Land Policies Between Regulation and Implementation], (Buku Kompas, Revised Edition, Jakarta, 2005), 87-91. 
the Procurement considering the

of Land for

Development

Interests principle of respect toward valid rights to land necessary to amend development of Presidential public interests, Regulation No. 36 there needs to be of the Year 2005 on land for which its the Procurement of procurement is Land for Execution carried out by of Development of prioritizing the Public Interests principles of humanity, democracy, and fairness

$\begin{array}{llll}\text { Great } & \text { Great } & \text { Great } & \text { Three components } \\ \text { bestuursbevoegd } & \text { bestuursbevoegd } \\ \text { heid } & \text { heid } & d & \begin{array}{l}\text { (bevoegdheid) are } \\ \text { apparent }\end{array}\end{array}$

- Although the two presidential regulations respect the valid rights to land, they do not provide an authentic interpretation of the meaning of "public interests";

- The National Land Agency (BPN) has not positioned as the arbitrary institution in the land procurement committee;

- There is a conflict with the principle of justice in a legal state (rechtsstaat) because it does not provide access to justice for justice seekers (not justifiable) There needs to be a legal explanation that clarifies the three components of authority, which are influence, legal basis, and legal conformity ${ }^{27}$

\section{c. Legal Theory}

This article articulates legal theory as a theory that is developed from the concept of law by experts of administrative law, particularly administrative authority (bestuursbevoegdheid) regarding land procurement for development of public interests, which is in line with the three foundations of administrative law of the legal state, democracy, and instrumental character. ${ }^{28}$ This matter has considered important because:

1. The legal state (Rechtsstaat) as the foundation that ensures legal protection of government authority covers the principle of legality of government execution (rechtmatigeheid van bestuur), involving authority, procedure, and substance;
2. Democracy is related to the procedure and substance in a government organization, whether for decisionmaking or actual legal actions, based on the principles of the presence of peoplerepresenting agencies, absence of lifelong offices (afzetbaarheid van bestuur), and participation (inspraak);

3. The instrumental character has the basis of effectiveness (doeltreffenheid) or efficacy, and efficiency (doelmatigheid) or productivity. ${ }^{29}$

Regarding the formation of a land procurement agency as the institution of the National Land Agency, based on Article 5 Letter f iuncto Articles 23-26 of Presidential Regulation No. 63 of the Year 2013 on the National Land Agency, there is the great expectation that this legal institution must be

27 Confer Philipus M Hadjon et al., Hukum Administrasi dan Tindak Pidana Korupsi [Administration Law and Crimes of Corruption], Second Printing, (Gadjah Mada University Press, $2^{\text {nd }}$ Printing, Yogyakarta, 2012), 1011; referring to the views of FAM. Stroink and Henc van Maarseveen, PM Hadjon emphasizes the components of authority as control of behaviors of legal subjects, which are influence from the government, including policy-making officials; legal basis, which must always be able to be indicated; and legal conformity, which means that there are standards of authority, including general standards (for all kinds of authority) and specific standards (for certain kinds of authority).

28 Ibid, 6.

29 Ibid, 6-7. 
able to perform its duties of formulating and executing policies in the field of land procurement for development of public interests as well as establish an authority for land rights with the primary tasks and functions having been established by Article 25 Presidential Regulation No. 63 of the Year 2013, which cover:

a. Formulation of technical policies in the field of land procurement;

b. Land evaluation, land consolidation, land regulation, and establishment of land authority;

c. Execution of land evaluation and land consolidation management;

d. Technical development for Land Evaluators;

e. Execution of land procurement for development of public interests;

$f$. Execution of guidance and development for land procurement for development of public interests;

g. Regulation and establishment of rights to land authority for public interests and land authority; and execution of other duties assigned by the Chief.

In line with this, and about Presidential Regulation No. 71 of the Year 2012 on the Organization of Land Procurement for Development for Public Interests, the regulatory politics of this presidential regulation is for the execution of the stipulation of Article 53 Paragraph (3) and Article 59 of Law No. 2 of the Year 2012 on Land Procurement for Development for Public Interests, for which the establishment of a Presidential Regulation on the Execution of Land Procurement for Development for Public Interests is required, and has the legal consequences of concordance and harmony in legal concept and theory with:

1. The national philosophy of Pancasila, 1945 Constitution, and Law No. 5 of the Year 1960;

2. The three bases of administrative law, which are the legal state, democracy, and instrumental character as a policy that is public; and
3. Principles of democracy and upholding human rights.

The explanation above serves as a contribution for the institution of the National Land Agency, which possesses the mandate to execute government policies in the field of land, for the execution of the policy whether at present or in the future to be able to be carried out as well as possible, to eliminate conflicts by upholding the principles of justice, legal certainty, and utility.

The Challenge and Strategic Strategy to Resolve the Issues in The Application of institutional Policy in land Procurement for Public Interest in The Omnibus Law Regime.

a. The challenges of using the approach of legal culture in activities of land procurement for public interests in the omnibus law era.

There are certainly several questions that come forward: how can modern law, which is capitalistic-liberal coexist, harmoniously with adat (customary) legal systems with their local wisdom and oral traditions $?^{30}$ What is the future of adat lands, which are regulated in the adat legal culture and have existed before the establishment of the Indonesian state, and are being repressed by national law containing the creed of a democratic legal state that facilitates both domestic and foreign investors through the omnibus law (formulated as the proposed law on the creation of employment) to be able to take over adat lands with the pretext of public interests? It is not easy to answer the above questions with logical argumentations that have based on the interests of society, particularly for people who are disadvantaged or marginalized. Thus, the efforts to answer the aforementioned questions accordingly are conducted by these philosophical bases:

a. Legal politics, material law, and formal law must refer to the values contained in the principles of Pancasila;

30 Sulistyawati Irianto, above n. 19, 8. 
b. Legal politics ought to be translated into legal practice containing the substance of articles that reflect concrete formulations of the essential or fundamental values of the principles of Pancasila;

c. The government must consider with the "emic" approach that according to the standpoint of the people as landowners in an agrarian country such as Indonesia, the land is the most valuable asset and concerns the selfrespect of people and their society. Therefore, the land along with the objects that lie on top of it, cannot simply be regarded merely as stationary objects that possess economic value and utility value. Henry Bernstein posed four fundamental questions that must be answered by the state: first, who has what (the ownership structure of agrarian resources, including land); second, who does what (occupational relations linked with agrarian resources); third, who gets what (production of added value from the production process of agrarian resources); and fourth, what has done with these values (appropriation and accumulation of added value from agrarian or land resources). ${ }^{31}$ Land that has a history that is in line with the history of its subject must be regarded as having a very close relationship with the culture where the land is located and its rights subjects, which are inseparable from the characteristics of religio magis, prima ad facie, and free and prior informed consent. This matter is implied by Article 5 of Law No. 5 of the Year 1960 that land or agrarian law in Indonesia has based on adat law. ${ }^{32}$ As such, the government in the name of

31 Henry Bernstein, Class Dynamics of Agrarian Change (Hallifax: Fernwood, 2010) Chapter 2; Iqra Anugrah, 'Persoalan Agraria dan Demokrasi di Indonesia' [Agrarian Affairs and Democracy in Indonesia], (2019) 38(3) Jurnal Prisma, 5.

32 The Adat law stated in Article 5 of the Law of Agrarian Affairs refers to Adat law that has been the state as the possessor of the popular sovereignty mandate, when in need of land for public interests based on Article 1 of Law No. 2 of the Year 2012, should execute the policy by accommodating the following:

1. Permission should be asked first to members of adat societies or communities regarding whether they are willing to cede their land as a form of nationalism to the government with compensation given, which has always understood to be merely in the form of money. Yet when examining the articles of Law No. 12 of the Year 2012, compensation other than money may be in the form of replacement lands, relocation, or additional stocks;

2. The perspectives in the regulations of land procurement for public interests are still narrow; they only regard land as being for parties who possess the protection of access, while adat people or societies that have initially claimed and stated their village adat lands are not rights subjects who possess inherent rights (rights that have existed innately from birth). The reinforcement of rights only occurred with Constitutional Court Verdict No. 35/PUU-X/of the Year 2012, May 16th, 2013 for, which the implementation still requires execution and reinforcement.

3. Referring to Article 36 of Law No. 2 of the Year 2012, the provision of compensation involves 1) plots of land, 2) buildings or other permanent structures that stand on the plots of land, and/or 3) plants that are embedded on the soil, both

filtered or cleaned to remove faults or defects that are not in harmony with the essence of Pancasila principles as well the populistic character of Indonesia, which is pluralistic-religious, prioritizes harmony, maintains unity, and rejects disintegration. 
short-lived and long-lived, that are affected by land procurement, which can be compensated by the government in the form of a) money, b) replacement land, c) resettlement, d) land ownership, or e) other forms agreed upon by the two parties.

The mindset or thought pattern of legal culture adopted by the government, particularly as the party that requires land for public interests, involves money. In reviewing various cases land procurement for public interests, none of these attempt to apply the breakthrough process that has based on utility and justice to utilize compensation in the form of stock inclusion based on the results of calculations performed by independent appraisers on land plots, structural objects, and or permanent objects and plants present on the land. Conversion of the values of objects in this way must utilize a benchmark value that is the most beneficial for subjects who formerly held rights over their land. It should not be that the calculations for the inclusion of stocks are instead made regarding the party that requires land. Therefore, in the context of legal culture, there need to be actual efforts to change the mindset of the government, Ministry of Agrarian Affairs and Spatial Planning, and other related ministries such as the Ministry of Public Works and Public Housing as well as the Ministry of Forestry and Environment to replace the scheme of compensation that ensures that landowners will experience losses. In contrast, parties who formerly held rights over land must position as the party that must gain benefits from the planned development activities for public interests. The conclusion that can be gained from the above is that, in correlation

33 Refer to Aditya Wicaksono et al., Meretas Kembali Jalan Panjang Pertanahan di Indonesia [Re-Exposing the Long History of Land Affairs in Indonesia], (Center of Research and Development of the Ministry of Agrarian Affairs and Spatial Planning/National Land Agency, Jakarta, 2014) 67-82, which does not address the legal affairs of land procurement policy practices that cause the marginalization of poor people and farmers, land conversion, changes to functions of forest areas, and relevance to the issue of land procurement for public interests with an omnibus law, it can be stated that the Law of Employment Creation has intended to replace and or revoke several stipulations of legal regulations to be collected and organized thematically to improve the achievement of the government aim of increasing investment. Land procurement for interests of development entails that the ease in dealing with land affairs will be improved, which means that the process will further facilitate interests of investment and is expected to expand employment opportunities. However, before the enactment of the Law of Employment Creation, the implementation practices of land procurement for public interests have resulted in conflicts and even disputes, not only diametrically but structurally, which have not been able to be resolved fairly. ${ }^{33}$ Seen from a cultural perspective, this indicates the presence of a national character that reflects a culture of "taking shortcuts", which prioritizes more on results than the activity itself as a process that always upholds corrective justice.

\section{b. The best strategy to resolve the issues in the application of institutional policies of land procurement.}

The best strategy that must be carried out by the government to resolve the issues in the application of institutional policies of land procurement for public interests. must consider the current omnibus law era. "Omnibus law" includes the word "omnibus" (from Latin) and is defined as an allencompassing law, which means a proposed law (bill) that contains more than one or several legal materials that have made into a

and so on. Compare with the report by the Ministry of National Development Planning/National Development Planning Agency, White Paper for the Policy of National Land Management, (Ministry of National Development Planning/National Development Planning Agency, 2013), 6-14, which also does not address the legal issue of conflicts of land procurement for public interests as a central issue. 
single law. ${ }^{34}$ As a comparison, the practice of omnibus law application in Canada according to Louis Massicotte refers to the vies of O Brien and Bosc (2009): "an omnibus bill seeks to amend, repeal or enact several Acts, and has characterized by the fact that it has several related but separate 'initiatives'... [Which] is an improvement over the previous edition." 35

According to Adam M Dodek, in reviewing the budgeting system for the creation of a new law through the simplification several existing legal regulations with certain aims, there needs to be a breakthrough from related ministers to provide budget items and an agreement with parliamentary representatives to regulate matters that have not been regulated by the inclusion of articles from related legal regulations to achieve legal utility, justice, and legal certainty. ${ }^{36}$ About the context of Indonesia and the correlation with activities of land procurement for public interests as regulated in Articles 1 and 2 as well as Article 33 Letter $f$ of Law No. 2 of the Year 2012, which will be affected by the enactment of the Law of Employment Creation (the Indonesian omnibus law), the most appropriate strategy to be applied in the

34 Maria Farida Indrati, Omnibus Law, Undangundang Sapu Jagat? [Omnibus Law: A Law of Everything?], Kompas, (January 4, 2020), 6; as a legal umbrella (raamwet/basiswet/moederwet), according to Maria Farida, it is understood as a new law that contains or regulates various kinds of legal substances and various legal subjects as an effort of simplification of various legal regulations that still apply (ius constitutum). An overview of its substance/content showed that it accommodates Article 10 Letter e of Law No. 12 of Year 2011 on the Formation of Legal Regulations with the aim of fulfilling the need for law in society. The critical question surely becomes, which society? It may need to deal with the society of those who own capital or in the elite group, or the society of people in unfavorable positions that first need to be corrected by the government to make their positions equal to that of the elite group as those who control access. The objectives of enacting the Law of Employment Creation (the omnibus law) are first, to resolve conflicts in legal regulations; second, to make the process of applying for permits more integrated, effective, and efficient; third, to augment relationships of coordination among institutions; regulating policy of the omnibus law has met fierce opposition from both scholars and grassroots activists. The middle path of legal politics, according to Bambang Kesowo, which is understood to contain political policies and the goals to be realized regarding all issues related to investment or for the simple goal of providing a direction for the principles of authority and simplification of permits for the ease of doing business in all fronts, is for the sake of employment creation. The other option is to implement change, removal, or repealing of certain laws that are perceived to hinder investment, which has then executed into amendments of certain laws. ${ }^{37}$ However, what becomes inevitable is that the issue of compensation in activities of land procurement for public interests must involve detailed calculations of the social price of socio-economic changes for the landowner until the landowner receives income from the new possessed assets by preventing the decline of the socio-economic status of the former landowner. Partiality has needed to the former landowner who is forced to change occupations or to go through a waiting period until the former landowner obtains new agricultural lands that become a new and more promising source of

fourth, to make government policies more uniform in three layers; fifth, to cut down the length of bureaucratic processes; and sixth, to ensure legal certainty and legal protection. The six objectives are certainly seen from a top-down perspective, and not bottom-up.

35 Louis Massicotte, Omnibus Bills in Theory and Practice, (Canadian Parliamentary Review/Spring 2013), 13; according to Massicotte, the case of the omnibus law proposal in Canada concerns the issue of the motive or aim of law formation, for example changing the technique of formation of legal regulations by conducting political lobbying to negotiate or in a way bargain their formation with governmentbacking political parties and opposition political parties, using socio-legal analysis of the behaviors of existing supporters of interests.

36 Adam M. Dodek, 'Omnibus Bills: Constitutional Constraints and Legislative Liberations', (2017) 48(1) Ottawa Law Review, 5-6 and 42.

37 Bambang Kesowo, Jalan Tengah Untuk RUU Cipta Kerja [A Middle Path for the Proposed Law on Employment Creation], Kompas, (March 6, 2020), 6. 
living for the former landowner and the associated family.

\section{CONCLUSION}

In brief, the correlation of the cultural approach and activities of land procurement is that culture refers to the target of the national conscience, and thus the cultural approach based on the growth mindset will result in wisdom and nobility of the decisions of public officials to prioritize the people rather than interests of investment. Fostering a conscience that will ultimately be reflected outward as the guide of the behaviors of those in charge, particularly public officials in making decisions of land procurement, is not an easy matter. The main pillar of all conscience that displays noble behaviors is the Pancasila.

The difficulty in using the legal culture approach in activities of land procurement for public interests in the omnibus law era may be responded to by finding how modern capitalistic-liberal law can coexist harmoniously with the adat legal system with its local wisdom and oral tradition through a legal culture approach that has aligned with local wisdom values based on an interdisciplinary approach.

The best strategy that must be carried out by the government to overcome difficulties in the application of institutional policies in land procurement for public interests in the omnibus law era includes political policies and the goals to be realized regarding all problems that are related to investment or the simple objective of providing a direction for the principles of authority and simplification of permits for the ease of doing business in all fronts for the sake of employment creation. The other option is to change, remove, or repeal certain laws, which has then executed into amendments of certain laws that are perceived to hinder investment.

The government needs to be firm in rejecting the conditions that are requested by investors, as major corporations, to commit denial of the harmony in legal politics and the substance of the employment creation law, including the law of land procurement for public interests with the values from the
Pancasila and the constitution. Dialogs need to be carried out more broadly and intensively to involve people from all levels of society to allow them to provide opinions openly and freely for the substance of an employment creation law that is juster. The government must choose to renegotiate the policy of enacting the Law of Employment Creation, which is judged by the greater public to conflict with the spirit and mandate of the Preamble and contents of the 1945 Constitution. If this renegotiation between the state and people by discussing in-depth the legal substance of the law is not performed, then the law in question must have its enactment firmly rejected.

\section{REFERENCES}

\section{Books and Report}

Bernstein, Henry, Class Dynamics of Agrarian Change (Hallifax: Fernwood, 2010).

Boen, Billy, Young on Top, 30 Rahasia Sukses di Usia Muda [Young on Top: 30 Secrets of Success at a Young Age], (TransMedia, Jakarta, 2009).

Donovan, James M., Legal Anthropology, An Introduction (Alta Mira Press, Lanham, UK, 2008).

Friedman, Lawrence M, The Legal System: A Social Science Perspective, (New York: Russel sage Foundation, 1977).

Hadjon, Philipus $\mathrm{M}$ et al., Hukum Administrasi dan Tindak Pidana Korupsi [Administration Law and Crimes of Corruption], Second Printing, (Gadjah Mada University Press, $2^{\text {nd }}$ Printing, Yogyakarta, 2012).

Irianto, Sulistyawati, Pendidikan Hukum Untuk Indonesia Masa Depan: Sebuah Catatan Kritis [Legal Education for a Future Indonesia: A Critical Remark], (Scientific Oration, Open Senate Meeting for the $74^{\text {th }}$ Anniversary of the Faculty of Law of Gadjah Mada University, Yogyakarta, 2020).

Kasali, Rhenald, Strawberry Generation, Mengubah Generasi Rapuh Menjadi Tangguh [Strawberry Generation: Changing a Fragile Generation to a 
Strong Generation], (Rumah Perubahan dan Mizan, Jakarta, 2017).

Koentjaraningrat, Kebudayaan, Mentalitet dan Pembangunan [Culture, Mentality, and Development], (Gramedia, $3^{\text {rd }}$ Printing, Jakarta, 2016).

Liam, Murphy and Thomas Nagel, The Myth of Ownership, (Oxford University Press, First Printing, New York, 2002)

McCoubrey, Hilaire, Nigel D White, 1996, Textbook on Jurisprudence, (Blackstone Press Limited, Second Edition, Glasgow).

McLeod, Ian, Legal Teory (Palgrave Macmillan, $4^{\text {th }}$ Ed, New York, 2007).

MD, Mohammad Mahfud, Membangun Politik Hukum, Menegakkan Konstitusi [Constructing Legal Politics, Upholding the Constitution], (Rajawali Pers, $2^{\text {nd }}$ Printing, Jakarta, 2011).

Notonagoro, Beberapa Hal Mengenai Falsafah Pancasila [Several Matters Regarding the Pancasila Philosophy], (Speech for the First Anniversary of Pancasila University, Djakarta, Eighth Printing, Pantjuran Tudjuh, Djakarta, 1979).

Pena, Tim Prima, n.d., Kamus Lengkap Bahasa Indonesia [Complete Dictionary of the Indonesian Language], (First Printing, Gita Media Press, n.p.).

Rawls, John, 1999, A Theory of Justice, (Belknap Press of Harvard University Press, Revised Edition, USA, 1999).

Tauhid, Mochammad, Masalah Agraria Sebagai Masalah Penghidupan dan Kemakmuran Rakyat Indonesia [Agrarian Affairs as an Issue of Livelihood and Prosperity of Indonesian People], Book One, (Bina Desa Foundation, Fourth Printing, Jakarta, 2011).

Setyowati, Agnes, Cultural Studies: Sebuah Pengantar, Teori dan Konsep [Cultural Studies: An Introduction, Theories, and Concepts], (Mitra Wacana Media, Bogor, 2019).

Sumardjono, Maria Sriwulani, Himpunan Kasus Beberapa Masalah Tanah [Compilation of Several Land Issue Cases], (Department of Agrarian Law,
Faculty of Law, Gadjah Mada University, First Printing, Yogyakarta, 1982).

Sumardjono, Maria SW, Kebijakan Pertanahan Antara Regulasi dan Implementasi [Land Policies Between Regulation and Implementation], (Buku Kompas, Revised Edition, Jakarta, 2005).

Wahono, Francis, Ekonomi Politik Daulat Rakyat: Pancasila Sebagai Acuan Paradigma, (Buku KOMPAS, $1^{\text {st }}$ Ed, Jakarta, 2020)

Wicaksono, Aditya et al., Meretas Kembali Jalan Panjang Pertanahan di Indonesia [Re-Exposing the Long History of Land Affairs in Indonesia], (Center of Research and Development of the Ministry of Agrarian Affairs and Spatial Planning/National Land Agency, Jakarta, 2014).

\section{Law}

Indonesia Constitution 1945.

Law No. 5 of the Year 1960 on basic Fundamental of Agrarian.

Law No. 2 of the Year 2012 on Land Procurement for Development.

Law No. 20 of the Year 1961.

Minister of Domestic Affairs Regulation No. 15 of the Year 1975.

Presidential Regulation No. 71 of the Year 2012 on the Organization of Land Procurement for Development for Public Interests

Presidential Decree No. 55 of the Year 1993 on the Procurement of Land for Conducting Development for Public Interests.

Presidential Regulation No. 63 of the Year 2013 on the National Land Agency, Presidential Regulation No. 63 of the Year 2013.

Presidential Regulation No. 71 of the Year 2012 on the Organization of Land Procurement for Development for Public Interests.

\section{Journal}

Anugrah, Iqra, 'Persoalan Agraria dan Demokrasi di Indonesia' [Agrarian 
Affairs and Democracy in Indonesia], (2019) 38(3) Jurnal Prisma.

Dodek, A Adam M., 'Omnibus Bills: Constitutional Constraints and Legislative Liberations', (2017) 48(1) Ottawa Law Review.

Kartodihardjo, Hariadi and Sudarsono Soedomo, 'Area Regime and the Politics of Its Usage Reallocation: A Historical, Management, Institutional, and Bureaucratic Overview' [Rezim Kawasan dan Politik Realokasi Penggunaannya: Tinjauan Historis, Tatakelola, Institusi dan Birokrasi], (paper for the National Symposium of Agrarian Reform Implies Forestry Reform, organized by IPB, ForciDeV dan FOReTIKA, Jakarta, 2020).

Massicotte, Louis, Omnibus Bills in Theory and Practice, (Canadian Parliamentary Review/Spring 2013).

Yusuf, Ria Mardiana and Muh Guntur, Menuju Kepemimpinan Yang Berkeadilan Sosial [Towards Leadership with Social Justice], in
Jurnal Keadilan Sosial, First Edition: Antara Keadilan Sosial dan Keadilan Hukum [Between Social Justice and Legal Justice], ILRC and OCI, Jakarta, 2010).

\section{News paper}

Arsyad, Idham, 'Sesat Pikir RUU

Pengadaan Tanah' [Misguided Views of the Land Procurement Bill], Kompas, (Friday, March 18, 2011).

Editorial, 'Ancaman Hak Atas Tanah' [Threat to Land Rights], Kompas, (Friday, March 11, 2011).

Kesowo, Bambang, Jalan Tengah Untuk RUU Cipta Kerja [A Middle Path for the Proposed Law on Employment Creation], Kompas, (March 6, 2020).

Indrati, Maria Farida, Omnibus Law, Undang-undang Sapu Jagat? [Omnibus Law: A Law of Everything?], Kompas, (January 4, 2020). 